\title{
Sources of reactive nitrogen affecting ecosystems in Latin America and the Caribbean: current trends and future perspectives
}

\author{
LUIZ A. MARTINELLI ${ }^{1, *}$, ROBERT W. HOWARTH ${ }^{2}$, \\ ELVIRA CUEVAS ${ }^{3}$, SOLANGE FILOSO ${ }^{2}$, AMY T. AUSTIN ${ }^{4}$, \\ LORETA DONOSO $^{5}$, VERA HUSZAR ${ }^{6}$, DENNIS KEENEY ${ }^{7,8}$, \\ LUCIENE L. LARA ${ }^{1}$, CARLOS LLERENA ${ }^{9}$, GEORGE MCISSAC ${ }^{10}$, \\ ERNESTO MEDINA ${ }^{11}$, JORGE ORTIZ-ZAYAS ${ }^{12}$, \\ DONALD SCAVIA $^{13}$, DAVID W. SCHINDLER ${ }^{14}$, DORIS SOTO ${ }^{15}$ \\ and ALAN TOWNSEND ${ }^{16}$
}

${ }^{1}$ CENA, Av. Centenário 303, 13416-000, Piracicaba, SP, Brazil, ${ }^{2}$ Ecology \& Environmental Biology Department, Cornell University, E311 Corson Hall, Cornell, Ithaca, NY 14853, USA; ${ }^{3}$ Department of Biology, College of Natural Sciences, University of Puerto Rico, PO Box 23360San Juan, Puerto Rico 00931-3360; ${ }^{4}$ Faculty of Agronomy, University of Buenos Aires and IFEVA-CONICET, Avenida San Martín 4453, C1417DSE, Buenos Aires, Argentina; ${ }^{5}$ Instituto Venezuelano de Investigaciones Cientificas - IVIC, Centro de Ecología, IVIC, Aptdo. 21827, Caracas 1020-A, Venezuela; ${ }^{6}$ Departamento de Botânica, Universidade Federal do Rio de Janeiro, Museo Nacional, Quinta da Boa Vista s/n, São Cristóvão - Rio de Janeiro, RJ 20940040, Brasil; ${ }^{7}$ Agriculture and Biosystems Engineering, Iowa State University, 3402 Eisenhower Ave., Ames, Iowa 50010, USA, ${ }^{8}$ Institute for Agriculture and Trade Policy, Minneapolis, Minnesota, USA $A^{9}$ Universidad Nacional Agraria La Molina, Apartado 456, Lima, Peru, ${ }^{10}$ Department of Natural Resources and Environmental Sciences, University of Illinois at Urbana Champaign, w-503 Turner Hall, 1102 South Goodwin Avenue, Urbana, IL 61801, USA; ${ }^{11}$ Instituto Venezolano de Investigaciones Cientificas, Laboratory Plant Physiological Ecology, Centro de Ecologia, IVIC, Aptdo. 21827, Caracas, 1020-A, Venezuela; ${ }^{12}$ Institute for Tropical Ecosystems Studies, University of Puerto Rico, PO Box 23341San Juan, Puerto Rico 00931$3341 ;{ }^{13}$ School of Natural Resources and Environment, University of Michigan, G520 Dana 1115, Ann Arbor, MI, 48109, USA; ${ }^{14}$ Ecology Department, University of Alberta, Z 811, Biological Sciences Bldg., 114 St-89 Ave, Edmonton, Alberta, T6G 2E1, Canada; ${ }^{15}$ Universidad Austral de Chile, Casilla 1327, Puerto Montt, Chile: ${ }^{16}$ INSTAAR and EPO-Biology, University of Colorado, 1560 30th St., Boulder, CO 80309, USA; *Author for correspondence(e-mail: martinelli@cena.usp.br; phone: + 5519-3429-4074; fax: + 55-19-3434-9210)

Received $\mathbf{\square}$; accepted in revised form 19 January 2006

Key words: Biomass burning, Caribbean, Latin America, Nitrogen, Reactive agriculture, Urbanization

Abstract. While the amount of reactive nitrogen circulating at the global level has increased markedly in the last century, the effects of this increase are largely seen at the regional level due to interacting ecological and socio-economic factors. In contrast with most other regions of the world, Latin America and the Caribbean (LA-Ca) stand out due to the fact that the major input of reactive nitrogen (Nr) still occurs naturally via biological nitrogen fixation (BNF) in natural ecosystems as opposed to anthropogenic inputs of synthetic fertilizer, fossil fuel combustion and cropping with leguminous species. Largely due to economic reasons, the consumption of fertilizer $\mathrm{N}$ in the LA-Ca region is still low in comparison with the average consumption of the world. However, the fertilizer $\mathrm{N}$ consumption is increasing at a much faster rate than that in developed regions of the world, like 
USA and Canada. The Nr production through BNF in cultivated plants that fix nitrogen (C-BNF) is 5 times lower than that occurring naturally in Latin America, but is still equivalent to $16 \%$ of the world C-BNF. The cultivation of nitrogen-fixing crop species in the LA-Ca region is also increasing, almost entirely due to the expansion of soybean fields in the central and northern regions of Brazil and the Pampa region of Argentina. Other anthropogenic activities in the region that contribute to an increase in the circulation of reactive nitrogen include the impact of biomass burning and urbanization. In the last decade, an average of $47,000 \mathrm{~km}^{2}$ per year of forests was burned in the LA$\mathrm{Ca}$ region. The environmental impact of urban centers in the LA-Ca region has become very important, since an intense urbanization process is occurring in this region, at an intensity that far exceeds urban development in the northern hemisphere. The consequences of increased urbanization include increased emissions of $\mathrm{NO}_{x}$ to the atmosphere due to the fossil fuel combustion, and the lack of sewage treatment facilities in most cities of the LA-Ca result in a large volume of untreated sewage discharged into surface waters, creating serious environmental problems. The combination of rapid urbanization and agricultural intensification in this region suggest that concern is warranted for the potential for increase in the circulation of reactive nitrogen in the very near future. At the same time, the opportunity still exists to mitigate some of the consequences of human impact on the nitrogen cycle in a region that still maintains a large fraction of its natural ecosystems intact.

\section{Introduction}

The concentration of reactive nitrogen $(\mathrm{Nr})$ on the Earth has dramatically increased in the last century due mainly to the production of synthetic nitrogen fertilizer through the Haber-Bosch process, fossil fuel combustion, and the cultivation of plants that associate with bacteria that fix atmospheric N (Howarth et al. 2002; Galloway et al. 2004). It has been estimated that in 1860 the production of anthropogenic $\mathrm{Nr}$ was $15 \mathrm{Tg} \mathrm{N} \mathrm{yr}^{-1}$, and that by the early 1990's it increased by almost 10 times to approximately $140 \mathrm{Tg} \mathrm{N} \mathrm{yr}^{-1}$ (Galloway et al. 2004). Although these estimates are important in providing a global picture of the alteration of the $\mathrm{N}$ cycle by human activity, they do not allow us to propose actions that would help mitigate the deleterious effects of $\mathrm{N}$ in the environment and for human health occurring at regional or local scale. Much more detailed spatial information on the production and fate of $\mathrm{Nr}$ is needed to propose such actions.

Galloway et al. (2004) investigated geopolitical $\mathrm{N}$ budgets and showed that Latin America stands out as the region with highest inputs of $\mathrm{Nr}$ by naturally occurring biological nitrogen fixation (BNF) - an amount equivalent to $25 \%$ of the world's $\mathrm{Nr}$ created in terrestrial ecosystems. The $\mathrm{Nr}$ production through BNF in cultivated plants that fix nitrogen (C-BNF) in 1995 was 5 times lower than that occurring naturally in Latin America, but was still equivalent to $16 \%$ of the world C-BNF. On the other hand, Latin America was responsible in 1995 for only $6 \%$ of the world's $\mathrm{Nr}$ created through fossil fuel combustion, and for only $4 \%$ of the $\mathrm{Nr}$ originated from synthetic $\mathrm{N}$ fertilizer (Galloway et al. 2004).

In this paper, we provide an evaluation of the origin of reactive nitrogen in Latin America, and compare it to other areas of the world. The contrasts between impacts at the global and regional scale may help to suggest ways in 
which we can mitigate the deleterious effects of human impact on the $\mathrm{N}$ cycle in the coming decades. Assessing not only the current state of human impact, but the velocity of change in this region highlights the importance of focusing on regions where the potential human impact in the coming decades will be large, and where preventative steps could be taken to minimize the negative impacts of human-induced changes in nitrogen cycling.

\section{The geography and socio-economic aspects of the Latin America and the Caribbean (LA-Ca) regions}

\section{Geography}

Because statistics are generally categorized by country or political unit in most data bases, we define Latin America and the Caribbean, including their countries and territories, as shown in Table 1 (http://www.cia.gov/cia/publications/factbook/geos/cj.html).

The most typical definition of Latin America is the one that considers the countries of South America, Central America, the Caribbean, and southern North America that speak a Romance language, including Spanish, Portuguese, and French (Table 1). The Caribbean is defined as a group of islands located in the Caribbean Sea, organized in 25 distinct political units, including states and territories (Table 1). Geographical or economical and social indexes are available for most independent countries and, in some cases, for political units as well. For example, Puerto Rico is a commonwealth of the United States (US), and as a result, its data are sometimes aggregated to that the US statistics, while in other cases, they are reported as an independent political unit. As most production and use of $\mathrm{Nr}$ is linked to economic indicators, such as use of fossil fuel, fertilizer use, and cultivation of commercially important plants that have $\mathrm{N}$-fixing symbioses, it is useful to provide Latin American economic and social indicators for context.

\section{Social and economical indicators}

The Gross Domestic Product (GDP) index (Human Development Report 2003), (defined as the total value of goods and services produced by a nation and expressed on a per capita basis) varied from 0.48 to 0.83 for LA-Ca countries in 2003 (Figure 1).

Approximately $40 \%$ of the LA-Ca countries had a GDP index higher than the overall average for developing countries (0.70). Bolivia and Nicaragua had indexes only slightly higher than 0.5 , while Haiti was the only country with an index lower than the average of the least developing countries (0.5). (Figure 1). The highest indexes were observed in the Bahamas and Barbados. However, both values were significantly lower than the average of the richest countries of 
Table 1. List of countries in Latin America (LA) and the Carribean.

\begin{tabular}{|c|c|c|}
\hline Political unity & Region & Status \\
\hline 1-Anguilla & Caribbean & Territory of UK \\
\hline 2-Antigua and Barbuda & Caribbean & Independent country \\
\hline 3-Aruba & Caribbean & Territory of the Netherlands \\
\hline 4-Bahamas & Caribbean & Independent country \\
\hline 5-Barbados & Caribbean & Independent country \\
\hline 6-British Virgin Islands & Caribbean & Territory of UK \\
\hline 7-Cayman Islands & Caribbean & Territory of UK \\
\hline 8-Cuba & Caribbean (LA) & Independent country \\
\hline 9-Dominica & Caribbean & Independent country \\
\hline 10-Dominican Republic & Caribbean (LA) & Independent country \\
\hline 11-Grenada & Caribbean & Independent country \\
\hline 12-Guadeloupe & Caribbean (LA) & Territory of France \\
\hline 13-Haiti & Caribbean (LA) & Independent country \\
\hline 14-Jamaica & Caribbean & Independent country \\
\hline 15-Martinique & Caribbean (LA) & Territory of France \\
\hline 16-Montserrat & Caribbean & Territory of UK \\
\hline 17-Netherlands Antilles & Caribbean & Territory of the Netherlands \\
\hline 18-Puerto Rico & Caribbean (LA) & Commonwealth USA \\
\hline 19-Saint Kitts and Nevis & Caribbean & Independent country \\
\hline 20-Saint Lucia & Caribbean & Independent country \\
\hline 21-Saint Vincent/Grenadines & Caribbean & Independent country \\
\hline 22-SouthGeorgia/Sandwich Is & Caribbean & Territory of UK \\
\hline 23-Trinidad and Tobago & Caribbean & Independent country \\
\hline 24-Turks and Caicos Is & Caribbean & Territory of UK \\
\hline 25-Virgin Islands - US & Caribbean & Territory of US \\
\hline 26-Belize & Central America & Independent country \\
\hline 27-Costa Rica & Central America (LA) & Independent country \\
\hline 28-El Salvador & Central America (LA) & Independent country \\
\hline 29-Guatemala & Central America (LA) & Independent country \\
\hline 30-Honduras & Central America (LA) & Independent country \\
\hline 31-Nicaragua & Central America (LA) & Independent country \\
\hline 32-Panama & Central America (LA) & Independent country \\
\hline 33-Mexico & North America (LA) & Independent country \\
\hline 34-Argentina & South America (LA) & Independent country \\
\hline 35-Bolivia & South America (LA) & Independent country \\
\hline 36-Brazil & South America (LA) & Independent country \\
\hline 37-Chile & South America (LA) & Independent country \\
\hline 38-Colombia & South America (LA) & Independent country \\
\hline 39-Ecuador & South America (LA) & Independent country \\
\hline 40-Falkland Is (Malvinas) & South America & Territory of UK \\
\hline 41-French Guiana & South America (LA) & Territory of France \\
\hline 42-Guyana & South America & Independent country \\
\hline 43-Paraguay & South America (LA) & Independent country \\
\hline 44-Peru & South America (LA) & Independent country \\
\hline 45-Suriname & South America & Independent country \\
\hline 46-Uruguay & South America (LA) & Independent country \\
\hline 47-Venezuela & South America (LA) & Independent country \\
\hline
\end{tabular}




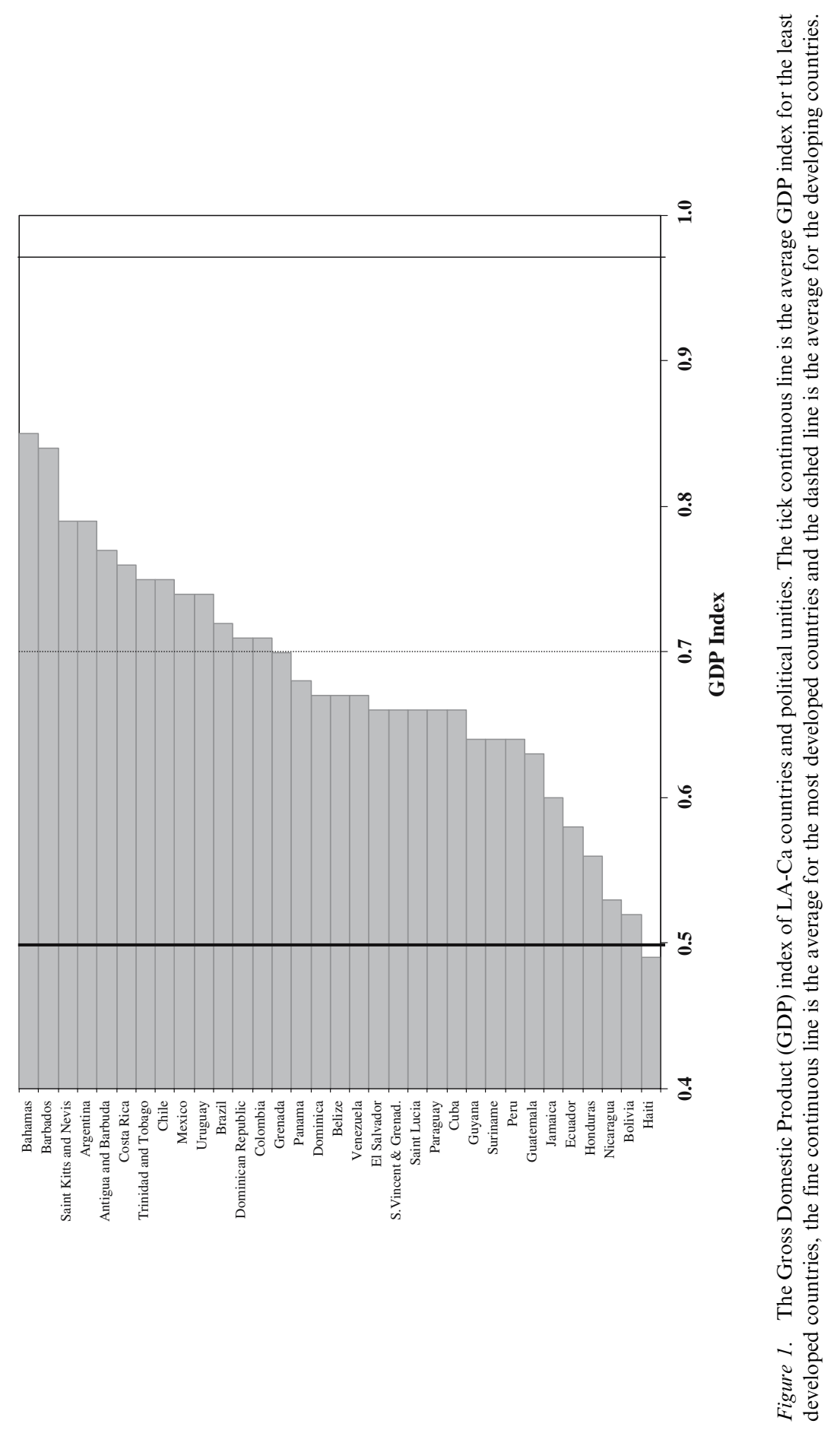


the world (Figure 1). The Human Development Index (HDI - Human Development Report 2003) is a weighted index which includes life expectancy, level of education, and GDP per capita. For the LA-Ca region, the HDI varied from 0.45 to 0.88 (Figure 2), while the average HDI for developing countries is 0.6. With exception of Haiti, all LA-Ca countries had indexes above that value. Barbados and Argentina had the highest HDI in the region but, again, the values were lower than those for the richest countries in the world.

Considering these two indexes together, as well as an index for poverty not shown here (Human Development Report 2003), it is clear that LA-Ca has an intermediate position in relation to the richest developed and the least developed countries of the world.

Finally, it is useful to assess the status of sanitation in LA-Ca, because lack of proper treatment of domestic sewage is an important issue in alteration of the $\mathrm{N}$ cycle. Sewage is processes at some level in most LA-Ca countries (Figure 3); however, 9 of 33 countries, of which two are the most populated countries in the region (Mexico and Brazil) have an index of sanitation (the percentage of the population with access to adequate excreta disposal facilities, such as a connection to a sewer or septic tank system, a pour-flush latrine, a simple pit latrine or a ventilated improved pit latrine - Human Development Report 2003), lower than the average for developed countries, indicating that a large fraction of the sewage is discharged untreated to waterways.

\section{Land use in Latin America and the Caribbean}

\section{Land use}

The main land use in LA-Ca is for pasture. Total world pasture area in 2002 was 3.5 billion ha, with approximately $18 \%$ ( 0.62 billion ha) of this in the LA-Ca region (FAOSTAT 2004). In South America, $80 \%$ of the area devoted to agriculture areas is under management for pasture, followed by $70 \%$ in Central America, and $50 \%$ in the Caribbean. Five countries are responsible for about $80 \%$ of pasture area in LA-Ca - Brazil (32\%), Argentina (23\%), Mexico $(12 \%)$, Colombia (7\%), and Bolívia (6\%). Most pasture land in LA-Ca are used for cattle grazing, which are typically $\mathrm{C}_{4}$ grasses, and which are rarely fertilized with nitrogen. Almost $30 \%$ of the world's domestic cattle are located in the LA-Ca region. The largest stocks are located in Brazil (50\%), Argentina $(14 \%)$, Mexico (8\%), and Colombia (7\%).

The second most important LA-Ca land use is for cereal crops. The LA-Ca region is responsible for $8 \%$ of the world cereal production. In Central America, $40 \%$ of the arable land is used for cereals, followed by $33 \%$ in South America, and $26 \%$ in the Caribbean. Brazil $(38 \%)$, Mexico $(21 \%)$, and Argentina (21\%) are responsible for $80 \%$ of the cereal harvested in the area in 2003. In Brazil and Mexico, corn is byfar the most important cereal, while wheat is the main cereal cultivated in Argentina. Rice is the second most 


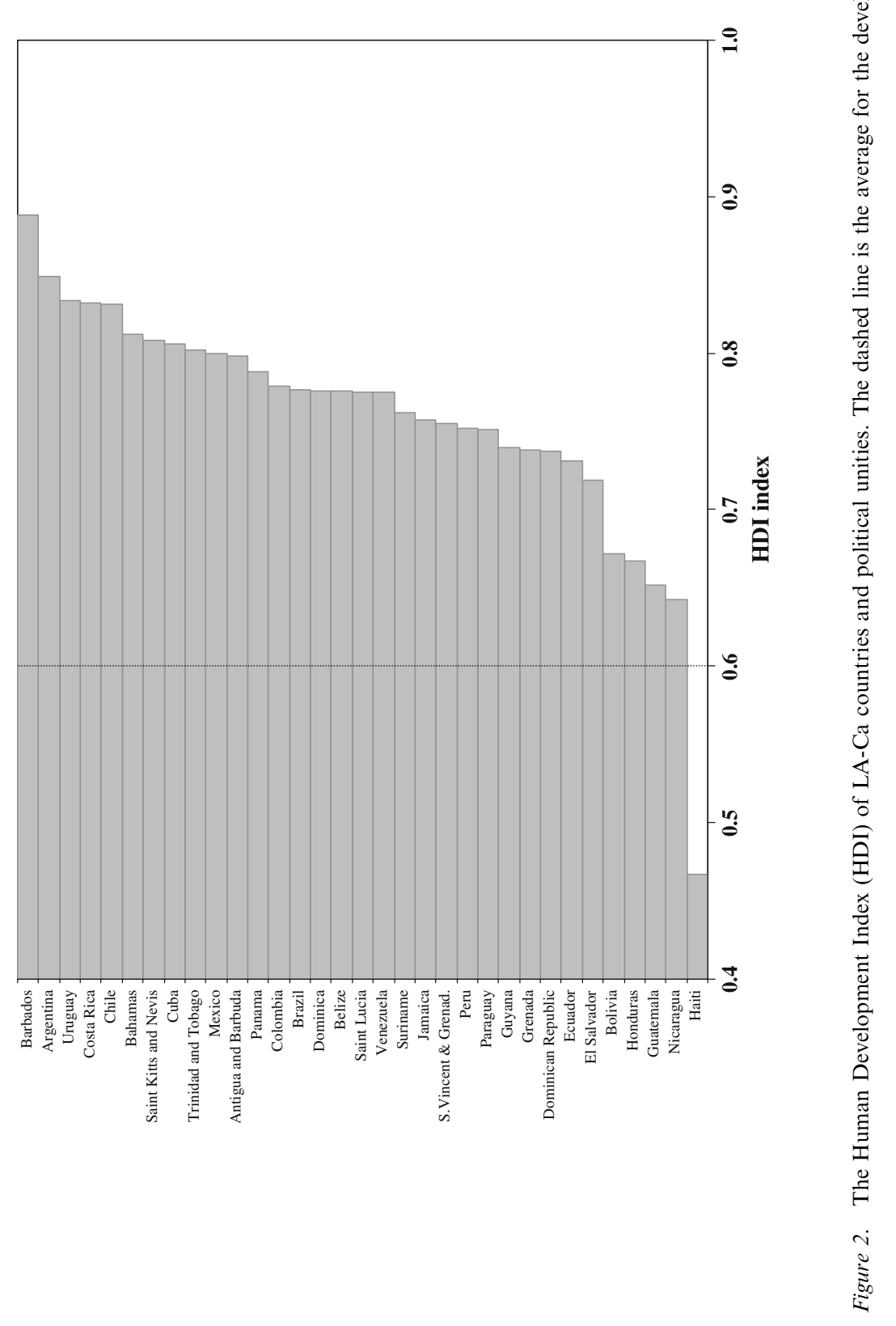




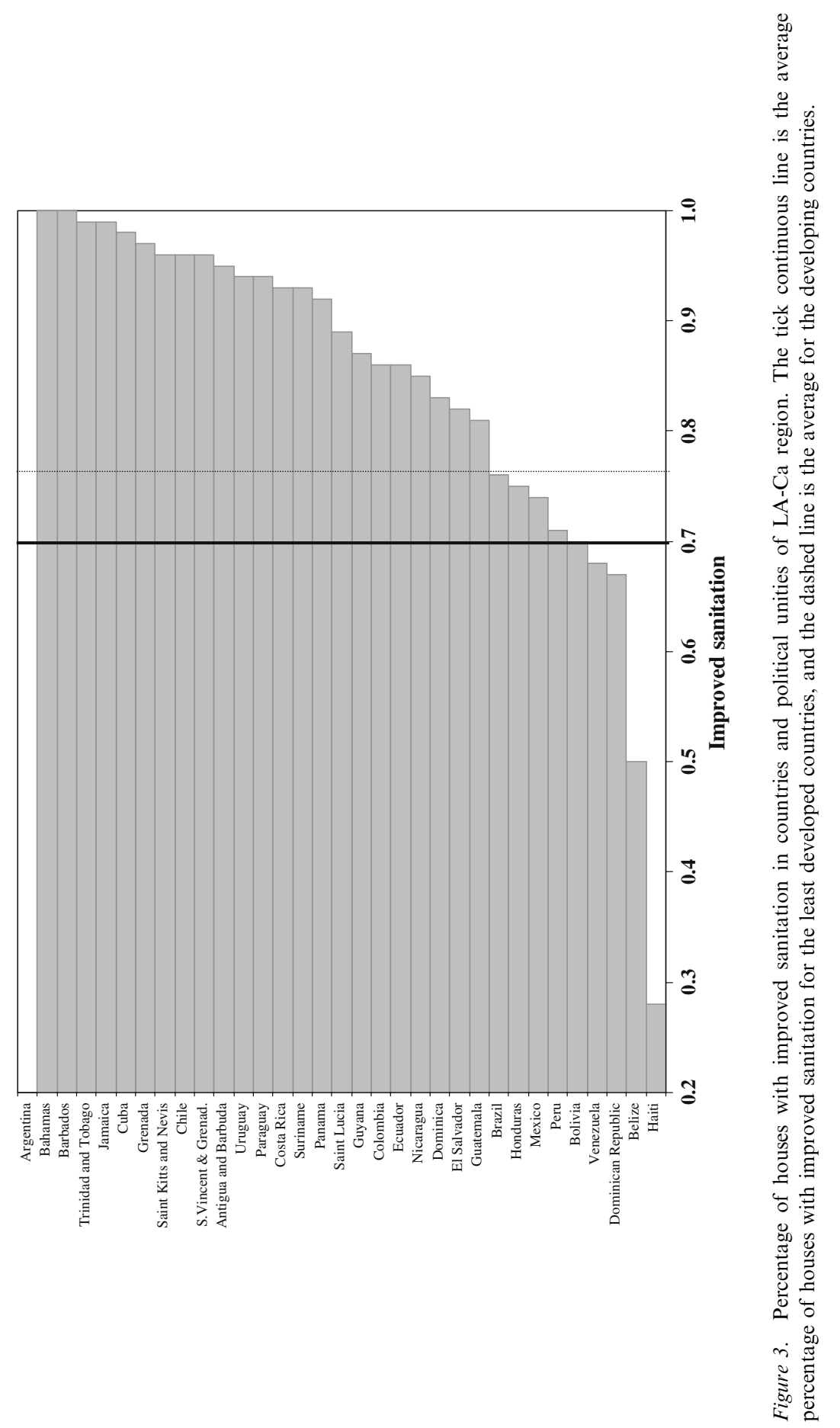


important in Brazil, and wheat is the second most important in Mexico, and corn is the second most important in Argentina.

\section{Fertilizer $N$ consumption in Latin America and the Caribbean}

In 2002 the LA-Ca region consumed approximately 5 million metric tons of fertilizer N, equivalent to $6 \%$ of the global consumption (FAOSTAT 2004). Three countries - Brazil, Mexico and Argentina - are responsible for almost $70 \%$ of the total fertilizer $\mathrm{N}$ consumption in the LA-Ca region (Figure 4).

The average application of fertilizer $\mathrm{N}$ per hectare of arable land in the LACa region is approximately $34 \mathrm{~kg} \mathrm{~N}^{-1}$ (see definition at FAOSTAT home page at http://www.apps.fao.org/default.jsp). Central America has the highest rate $\left(46 \mathrm{~kg} \mathrm{~N} \mathrm{ha}^{-1} \mathrm{yr}^{-1}\right.$ ), followed by South America and the Caribbean, with approximately $32 \mathrm{~kg} \mathrm{~N} \mathrm{ha}^{-1} \mathrm{yr}^{-1}$. These rates are below the world average of $60 \mathrm{~kg} \mathrm{~N} \mathrm{ha}^{-1}$, and well below rates for countries like China and the Netherlands where rates in 2002 were approximately 180 and $310 \mathrm{~kg} \mathrm{~N} \mathrm{ha}^{-1}$, respectively (FAOSTAT 2004). It is important to note that some countries in the LA-Ca region, such as Haiti and Bolivia,the rates are even lower than the average rate in the least developed countries $\left(13 \mathrm{~kg} \mathrm{~N} \mathrm{ha}^{-1}\right.$ in 2002) (Figure 5). On the other hand, small Central American countries (Costa Rica) and some islands of the Caribbean (Martinique and Guadeloupe) have high usage of fertilizer N (Figure 5); even higher than rates in the Netherlands. In these three countries the main land use are fruits and sugar cane, with banana and plantains the most important crops in terms of harvested area. Costa Rica also produces a variety of other fruits, especially citrus, pineapples, mangos and melons (FAOSTAT 2004). These rates of fertilizer application in the various countries represent the interaction among socio-economic factors such as availability and feasibility of fertilizer use as well as ecological factors including natural levels of fertility, crop selection and relative nutrient limitation by nitrogen vs. other nutrients.

Another way to characterize fertilizer use and to make it comparable with other countries is by reviewing per capita fertilizer consumption. The average value for LA-Ca is approximately $9 \mathrm{~kg} \mathrm{~N}$ per capita, almost 5 times higher than the average for the least developed countries of the world, but below the average for the whole world (14 $\mathrm{kg} \mathrm{N}$ per capita) and for developing countries (11 kg N per capita). Some small countries (St.Kits and Neives, Guadeloupe) and territories (Virgin Islands) of the Caribbean, and the Guyana in South America showed the highest consumption of fertilizer $\mathrm{N}$ per capita, with rates similar to those in China (19 $\mathrm{kg} \mathrm{N}$ per capita), but well below the USA (38 kg $\mathrm{N}$ per capita) or Canada (53 kg N per capita) (Figure 6). This relatively low per capita use of $\mathrm{N}$ fertilizer is mainly due to economic constraints, since most of the LA-Ca countries are net importers of fertilizer (FAOSTAT 2004). Venezuela is an exception, importing only $20 \%$ of the amount consumed. 


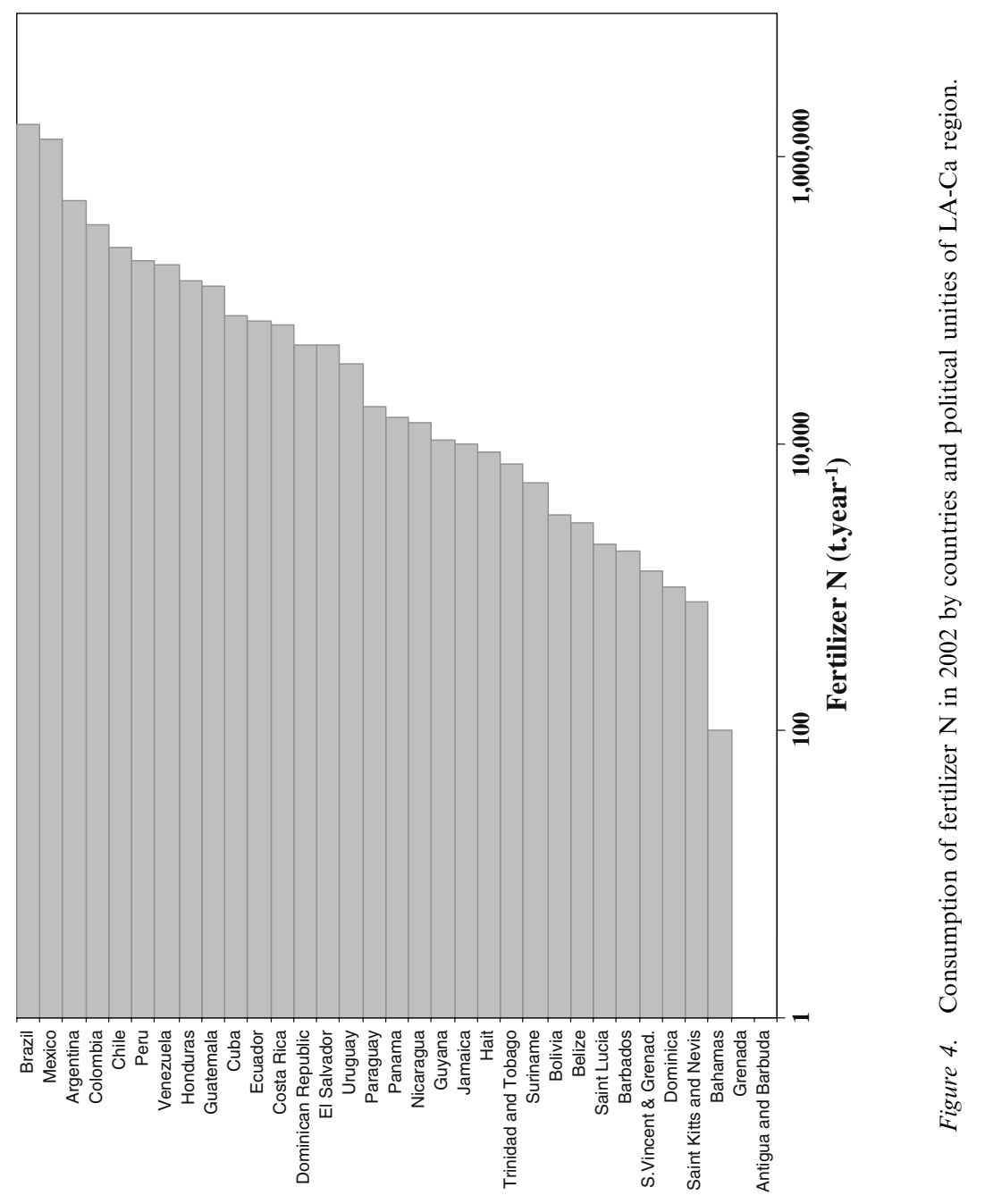




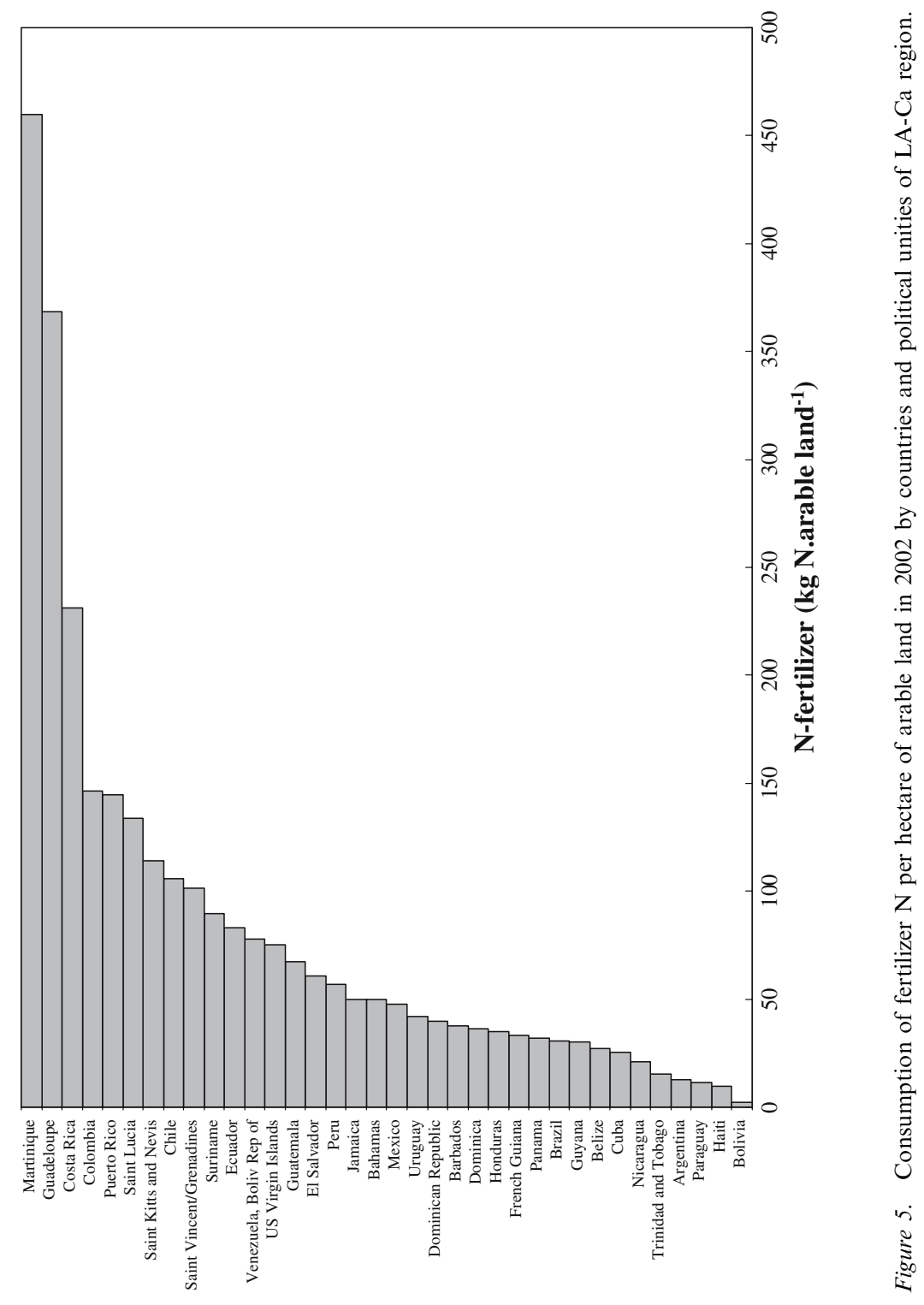




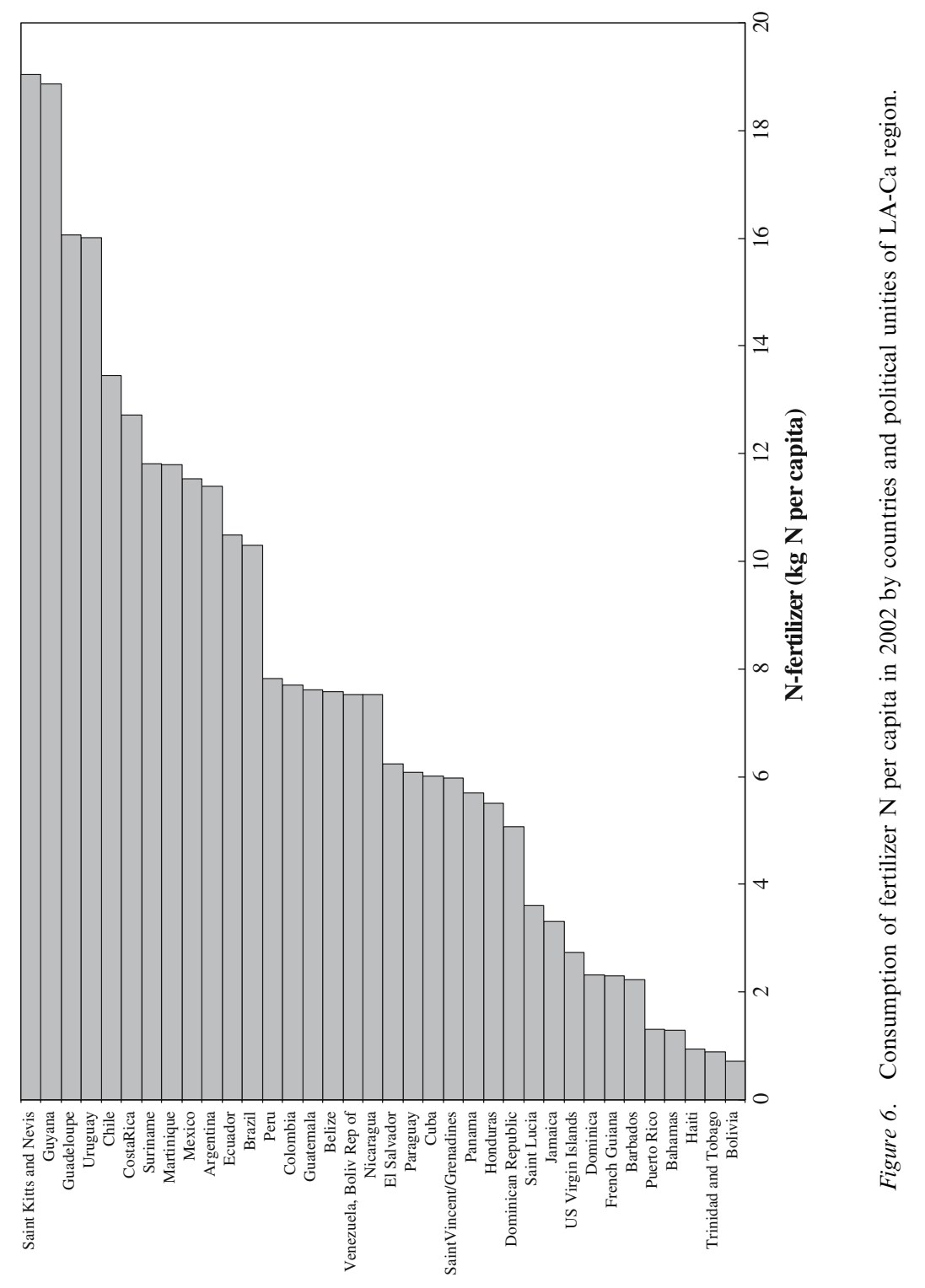


Brazil and Mexico import approximately $70 \%$ of their consumption; Argentina and Cuba importing approximately 50\% (FAOSTAT 2004).

Although fertilizer $\mathrm{N}$ use in LA-Ca is still relatively low, its trends are similar to the progressively increasing trends in Asia, in contrast with Europe and USA (Figure 7). The historical increase in fertilizer $N$ consumption in the three major Latin American consumers - Brazil, Mexico, and Argentina - has shown different trends (Figure 8). While Brazil had a constant and progressive increase since 1961, Argentina experienced a major increase in consumption only in the early 90's (Austin et al., this volume). Major growth in consumption in Mexico was achieved in the end of the 80 's, but since then no further increase has been observed (Figure 8).

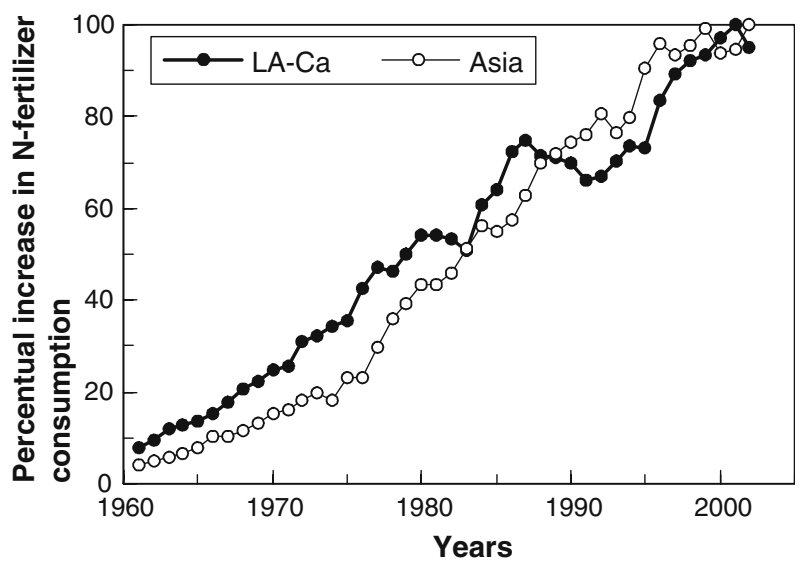

Figure 7. Percentage increase of fertilizer N consumption from 1960 to 2002 in LA-Ca, Asia, Europe and North America.

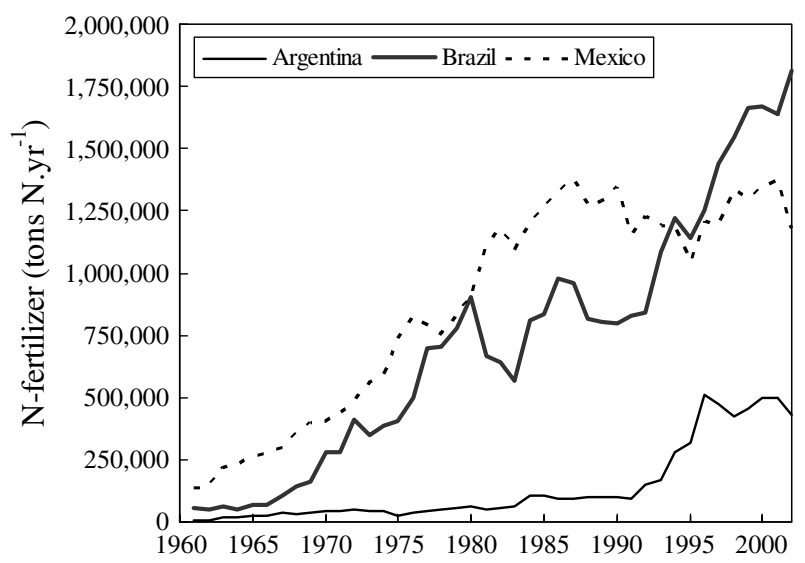

Figure 8. Consumption of fertilizer N from 1960 to 2002 in Argentina, Brazil, and Mexico. 


\section{$C-B N F$ historical trends in Latin America and the Caribbean}

Latin America and the Caribbean were responsible in 1995 for approximately $16 \%$ of the world's $\mathrm{N}$ fixation through cultivation of plants that have associations with bacterial N-fixers (C-BNF, Galloway et al. 2004). Three main landcovers that contribute to $\mathrm{C}-\mathrm{BNF}$ are soybean, pastures, and sugar cane. In 2003, approximately 33 million ha of soybean was harvested in LA-Ca, which is equivalent to $40 \%$ of the world production of this crop (FAOSTAT 2004). In 2002, the area harvested in LA-Ca exceeded the area harvested in the North America (Figure 9). Major producers of soybean in LA-Ca are Brazil (55\% of the harvested area), Argentina (38\%), Paraguay (5\%), and Bolivia (2\%). In Brazil, soybeans are able to obtain most of their required nitrogen from biological fixation (Boddey et al. 1991; Alves et al. 2003; Filoso et al., this volume); however, this is not the case in Argentina (Austin et al., this volume). Therefore an increase in the area cultivated for soybean in Latin America or in the Caribbean not necessarily implies an addition of newly fixed nitrogen through biological fixation.

As mentioned above, pasture is the main land use in LA-Ca, and the area covered with pasture showed an average increase of 2.6 million ha per year since 1961, in contrast to North America where pasture area has remained practically constant for the last four decades (Figure 10). Most of the nitrogen fixation in grasses like Brachiaria spp., Panicum maximum, and species of Pennisetum, that are extensively cultivated in South America, is derived from non-symbiotic associations with endophytic bacteria or from bacteria in the rizosphere (Miranda and Bodey 1987; Boddey et al. 2004; Filoso et al., this volume).

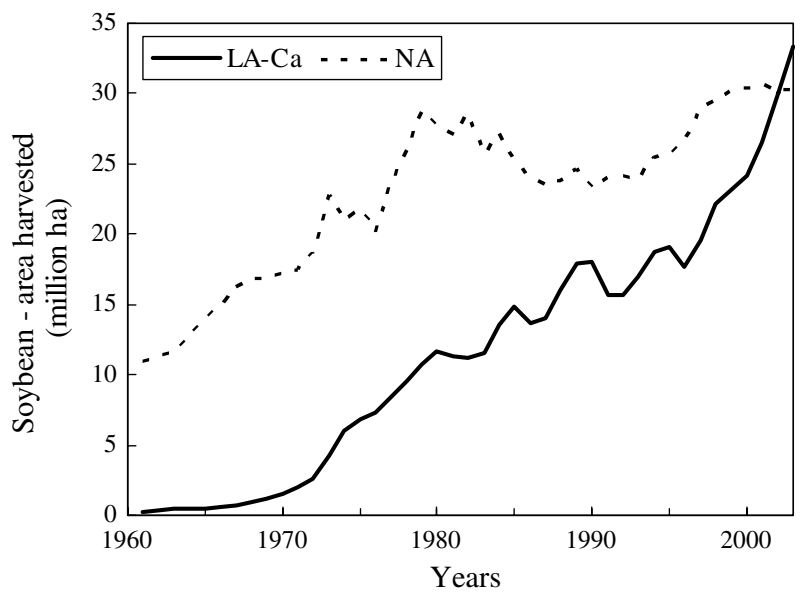

Figure 9. Increase in the area harvested with soybean in the LA-Ca and North America from 1960 to 2002 . 


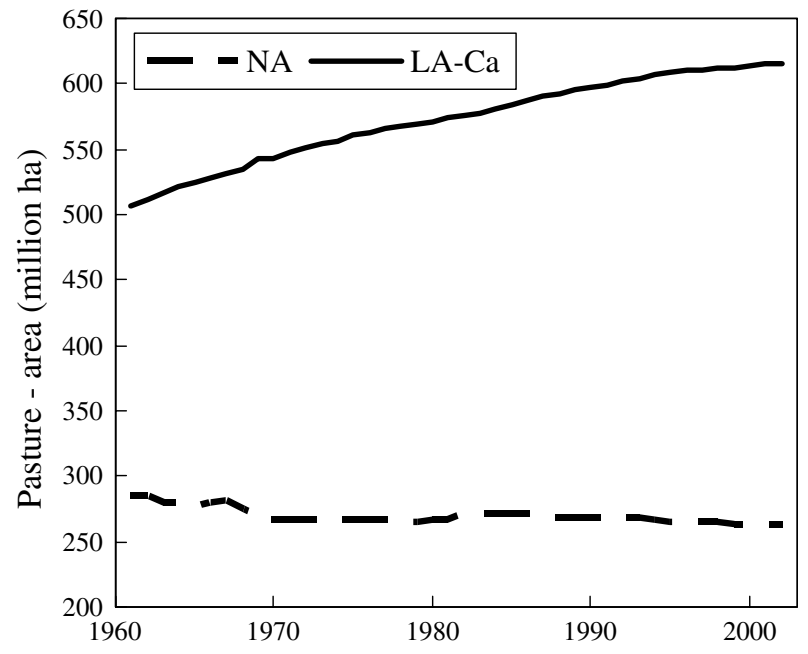

Figure 10. Increase in the pasture area in the LA-Ca and North America from 1960 to 2002.

The third crop that may contribute to C-BNF in the LA-Ca region is sugarcane (Boddey et al. 1991, 2003), which has been a traditional crop in this region (FAOSTAT 2004). Nearly $42 \%$ of the harvested area of sugar cane globally comes from Brazil, Cuba, Mexico and Colombia, and in the LA-Ca region alone, these countries account for $80 \%$ of the sugar cane production. The area devoted to sugar cane production increased markedly in the LA-Ca region between the beginnings of the 70's until the middle of the 80's (Figure 11), an increase that was led by Brazil, which is currently responsible for $62 \%$ of the

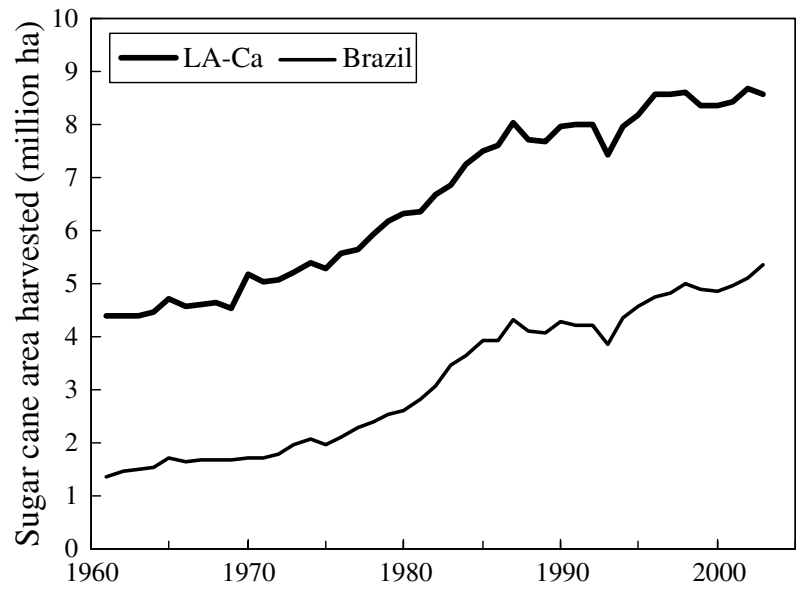

Figure 11. Increase in the area harvested with sugar cane in the LA-Ca region, Asia, Africa and Brazil from 1960 to 2002 . 
harvested area in the LA-Ca region. The rapid increase in sugar cane cropping stemmed from a series of fiscal incentives to increase sugar cane production for ethanol, a fuel used by Brazilian automobiles, has caused major increases in Brazilian production during this period (Oliveira et al. 2005).

Using current estimates for area in Latin America cultivated with soybean, pasture and sugar cane (shown above), and using equivalent biological nitrogen fixation rates and assumptions from Filoso et al. (this volume), we estimated C-BNF in Latin America for 2003 as approximately $10.5 \mathrm{Tg} \mathrm{yr}^{-1}$. This value is practically the double of the amount estimated by Galloway et al. (2004) for Latin America using land use data from 1995. We believe that this marked increase in the estimated amount of C-BNF for 2003 stems from the extensification in the cultivated area of soybean (Figure 9), pasture (Figure 10) and sugar cane (Figure 11) from 1995 to 2003.

\section{Biomass burning (source of $N$ to the atmosphere)}

Deforestation in LA-Ca between 1990 and 2000 averaged approximately $47,000 \mathrm{~km}^{2} \mathrm{yr}^{-1}$ (FRA 2000); Brazil alone was responsible for approximately half of that total $\left(23,000 \mathrm{~km}^{2} \mathrm{yr}^{-1}\right)$ (Figure 12). In Brazil, most of the deforestation is taking place in the Amazon region, where the average deforestation rates from 1988 to 2002 was approximately $18,000 \mathrm{~km}^{2}$ per year (INPE 2004). In the last 2 years deforestation rates increased to approximately 25,000 and $30,000 \mathrm{~km}^{2}$ per year, respectively.

In the Amazon region, most of the forest is converted to pasture for cattle through slash and burn methods during the dry season. Pasture is also burned every 4-5 years as a management method to 'clean the pasture' and eliminate the growth of shrubs and small trees. In southeastern Brazil, fire is also used during the dry season (May-September) prior to manual harvesting of sugar cane (which is the dominant method) to facilitate the process. In Central America and in the Andean countries, fuel wood is the major type of biomass burning. During clearing and burning of tropical rainforest, biomass-associated $\mathrm{N}$ is volatilized and a large fraction is emitted to the atmosphere in form of gaseous $\mathrm{NH}_{3}$ and $\mathrm{NO}_{x}$ (Trebbs et al. 2006).

Most estimates of $\mathrm{NO}_{x}$ emissions for tropical regions have been generated by models due to the lack of measurements. According to some models, the estimated $\mathrm{NO}_{x}$ emissions from biomass burning in LA-Ca ranges from 0.9 to $3.7 \mathrm{Tg}$ $\mathrm{NO}_{x} \mathrm{yr}^{-1}$, while global emissions range between 7.8 and $15.9 \mathrm{Tg} \mathrm{NO}_{x} \mathrm{yr}^{-1}$ (Galanter et al. 2000; Shultz 2002; Hoelzemann et al. 2004). On the other hand, Potter et al. (2002) estimated that, in the Amazon region alone, biomass burning produces $3.5 \mathrm{Tg} \mathrm{NO}_{x} \mathrm{yr}^{-1}$ emitted to the atmosphere, making this region the source of $20-33 \%$ of global $\mathrm{NO}_{x}$ emission fluxes to the atmosphere.

Most of the values predicted by models for $\mathrm{N}$ wet deposition in LA-CA ranged from 1 to $3 \mathrm{~kg} \mathrm{~N} \mathrm{ha}^{-1} \mathrm{yr}^{-1}$ (Dentener and Crutzen 1994; Holland et al. 1999; Galloway and Cowling 2002). However, some few studies in Brazil have 


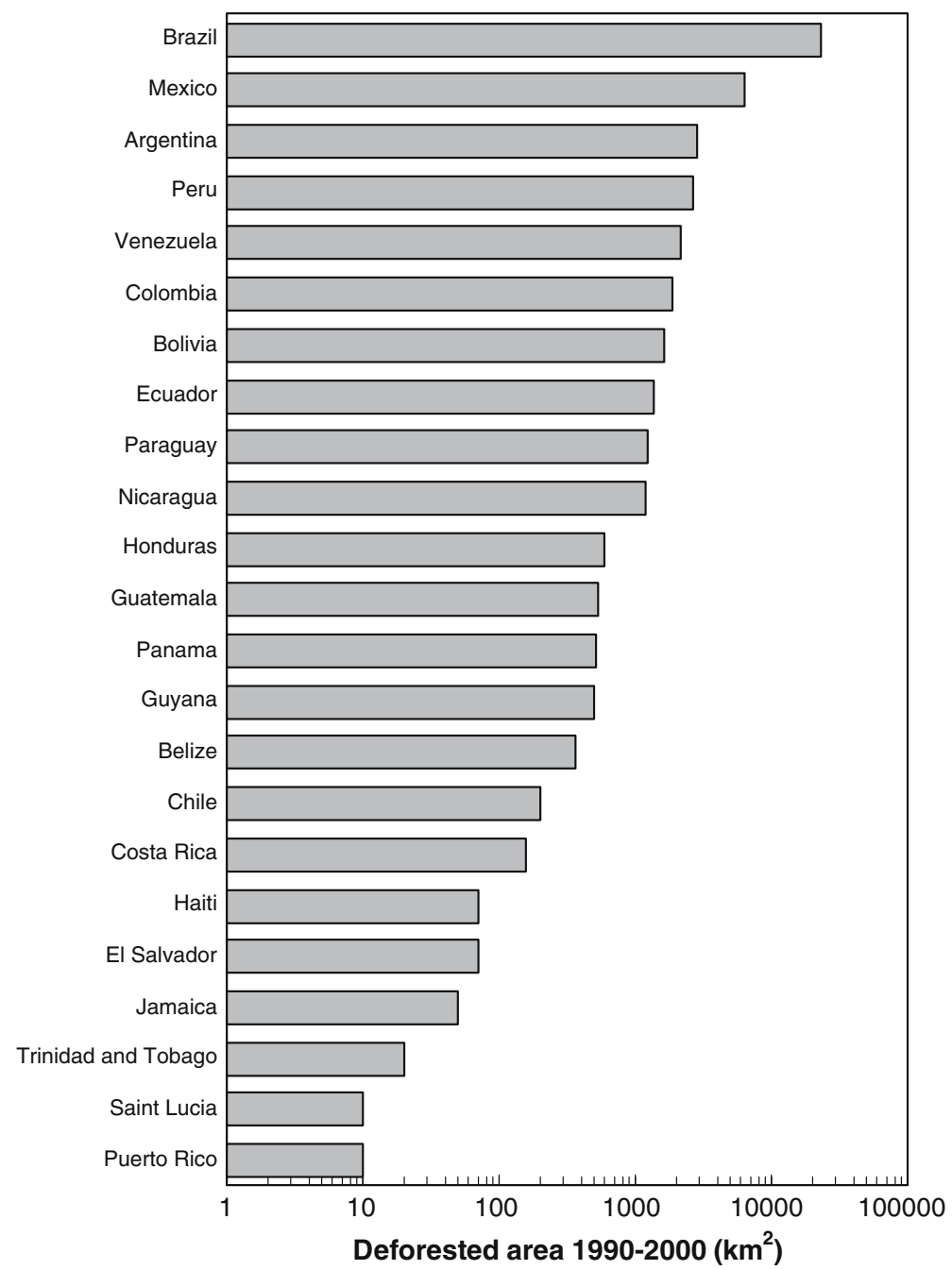

Figure 12. Deforested area from 1990 to 2000 in countries and political unities of the LA-Ca region.

measured a rate of $\mathrm{N}$ wet deposition around $1-2 \mathrm{~kg} \mathrm{~N} \mathrm{ha}^{-1} \mathrm{yr}^{-1}$ in more pristine areas (Williams and Melack 1997; Lara et al., this volume), while in disturbed areas the deposition is almost twice as much (Trebbs et al. 2006). In addition, the burning of biomass in either forests or sugar cane in Brazil is changing the dominant form of nitrogen deposition from nitrate to ammonium (W. Zamboni de Mello, University Federal Fluminense, personal communication). In the atmosphere, ammonium aerosols can reduce visibility, and may have negative effects on human health. Additionally, the formation of ammonium affects the atmospheric transport of $\mathrm{SO}_{2}$ and $\mathrm{NO}_{x}$ emissions. Once 
deposited, ammonium releases acidity since the nitrogen is either accumulated in organic form or nitrified and leached as nitrate (Schurkes and Mosello 1988). As biomass burning is one of the major sources of $\mathrm{N}$ to the atmosphere, several other regions in LA-Ca could be undergoing similar changes in the pattern of $\mathrm{N}$ deposition.

\section{Urbanization (fossil fuel and sewage)}

In 2003, approximately $48 \%$ of the world population lived in urban centers and urban areas covered approximately $2 \%$ of the Earth's land surface. It has been estimated that by 2030 , almost $61 \%$ of the world population will live in urban centers (World Urbanization Prospects 2003). However, the environmental impact of urban centers extends well beyond their limited spatial area due to the significant 'ecological footprints' of cities (Austin et al. 2003; World Urbanization Prospects 2003).

The Americas, defined here as the sum of North America, Latin America, and the Caribbean, had the highest percentage of their population living in urban centers in 2003 (78\%), followed by Europe and Oceania, with 75 and $73 \%$, respectively. Urbanization has increased rapidly. In 1950, the percentage in urban areas was only 53\% (World Urbanization Prospects 2003). In addition, 6 out of 20 mega cities of the world (population higher than 10 million people) are located in the Americas.

Although from 1950 to 2003 there was an increase in urbanization in North America, the highest increase was observed in Central and South America (Figure 13). In developing countries of Latin America and the Caribbean, migration was from rural to urban centers, while in North America both ruralto-urban migration and a migration from high density urban centers to low

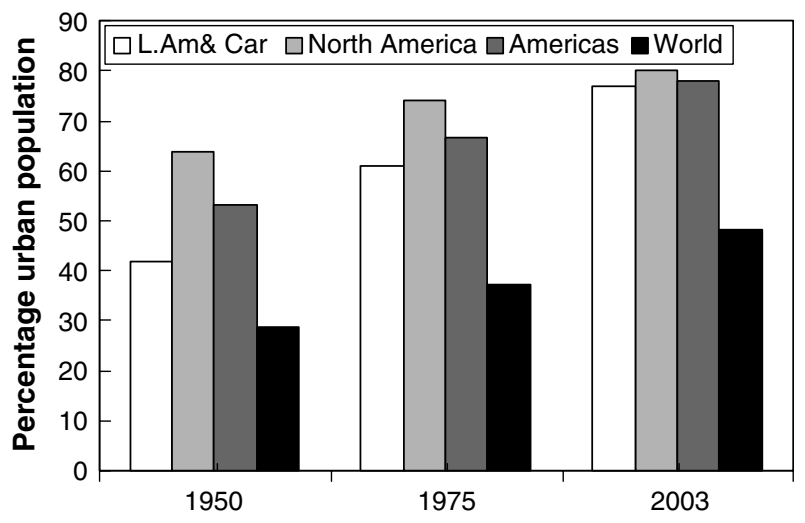

Figure 13. Percentage of urban population in Latin America and Caribbean, North America, Americas and World. Source: World Urbanization Prospects, 2003. 
density suburbs surrounding city cores (urban sprawl) occurred. In both cases, urbanization led to the concentration of domestic and industrial solid wastes, air pollution, and problems associated with lack of sewage treatment (Global Environmental Outlook 3 2003). Fewer than 35\% of cities in the developing world have their wastewater treated. In the Metropolitan area of São Paulo Brazil (with almost 18 million people) only $10 \%$ of the domestic sewage load is treated (Martinelli et al. 2002). In densely populated Caribbean regions, like Puerto Rico, urban sprawl is rapidly transforming the landscape. By 2000, nearly $50 \%$ of the 3.8 million inhabitants of Puerto Rico were connected to public sewer systems. Most of the wastewater, however, receives only primary treatment before it is discharged into the ocean. Consequently, a large volume of untreated sewage is discharged into surface waters, creating serious environmental problems. Similar situations are found throughout the developing countries of the Americas. Untreated domestic sewage is particularly rich in $\mathrm{NH}_{4}^{+}$and labile organic matter (Martinelli et al. 1999). The organic matter decomposes, consuming the dissolved oxygen concentrations in water bodies (Daniel et al. 2002). Under anaerobic conditions, $\mathrm{NO}_{3}^{-}$is denitrified and lost to the atmosphere while $\mathrm{NH}_{4}^{+}$accumulates in the water (Martinelli et al. 1999). In contrast, in North America $90 \%$ of urban sewage is treated (Global Water Supply and Sanitation Assessment 2000). However, most of this treatment is just for the removal of organic matter, and little effort has gone into removal of nitrogen from wastewater streams in most areas in North America, although increasingly such efforts are beginning.

In urban areas, residents rely mainly on fossil fuels for transportation. This is especially true in the United States and Canada due to, in part, to long-distance travel associated with urban sprawl. In 1975, a passenger drove approximately $8000 \mathrm{~km}$ per year; but by 1999 this distance increased to almost 15,000 km per passenger-year (Global Environment Outlook 3 2003). Also, in 1975, an average North American traveled about $300 \mathrm{~km}$ per year on public transportation, a distance very similar to that observed in 1999 (Global Environment Outlook 3 2003). Thus, over the last 24 years, the use of private transportation has increased drastically, while the use public transportation has remained stable.

Several industries that use fossil fuel as their main source of energy are also located in urban centers. Consequently, urban centers are responsible for increasing emissions of $\mathrm{NO}_{x}$. In the atmosphere, the dominant sink of $\mathrm{NO}_{x}$ is the oxidation of $\mathrm{NO}_{2}$ by $\mathrm{OH}$ to form $\mathrm{HNO}_{3}$, which then collects on aerosols or dissolves in precipitation and is subsequently deposited, causing rain acidification (Galloway 2003; Holland and Carroll 2003).

\section{Conclusion}

Current trends of economic development and human impact on $\mathrm{N}$ cycle in the LA-Ca region demonstrate levels of impact due to agricultural practices and urbanization which are, overall, less than that which is seen in more developed 
countries in the northern hemisphere. In Latin America, natural biological nitrogen fixation (BNF) is still an important source of $\mathrm{Nr}$ to the globe, accounting for $25 \%$ of the world's $\mathrm{Nr}$ created in terrestrial ecosystems (Galloway et al. 2004, in press). However, the rapid rate of change in almost all indicators of increased reactive nitrogen, from leguminous cropping, synthetic fertilizer use, biomass burning, and fossil fuel combustion merit concern for the potential impact of these indicators in the region in the very near future. For example, the increasing rates of deforestation and extensive conversion of natural ecosystems in Brazil and Argentina to cropping systems of soybean and other crops is a trend which is increasing at an alarming rate and whose consequences for the circulation of reactive nitrogen in the region and at the global level will be seen in the coming decades. While fertilizers are not yet heavily used in the LA-Ca region compared to other regions of the world, its consumption has been increasing constantly in most countries of the region. At the same time, it is important to call attention to the fact that in less developed countries of the LA$\mathrm{Ca}$ region, fertilizer $\mathrm{N}$ application currently does not adequately meet the food requirements of an increasing population (Mosier et al. 2004). Fire is extensively used in the LA-Ca region as the cheapest way to remove the natural vegetation for crops, and also to 'clean' pastures from bushes and small trees, and facilitate sugar cane harvesting. During burning, biomass associated $\mathrm{N}$ is volatilized and a large fraction is emitted to the atmosphere in form of gaseous $\mathrm{NH}_{3}$ and $\mathrm{NO}_{x}$. Part of this emitted nitrogen returns via wet and dry deposition. Increasing emissions of $\mathrm{NO}_{x}$ due to use of fossil fuel have been also observed in urban centers of LA-Ca region. Due to the migration of rural areas to urban centers, most of the cities in LA-Ca region have been growing very rapidly in these last three decades. This increase has not been followed by effective sewage collection and treatment. As a consequence, most of the domestic sewage is dumped without treatment in water bodies, leading to severe pollution problems.

The LA-Ca region, as a region undergoing rapid economic development, has both a challenge and an opportunity to produce food and use energy generated by fossil fuels in a way that keeps disruptions of the natural nitrogen cycle as small as possible. This developing region has the objective to meet the food and energy requirements of a growing population by using their natural resources to achieve such goals. However, the LA-Ca region has a unique opportunity to carry out this task without the same mistakes that have occurred in other areas of the world, where high rates of fertilizer application and mismanagement of reactive nitrogen has resulted in a number of negative consequences both for natural and managed ecosystems.

\section{Acknowledgements}

Thanks to the organizers of the various workshops in Ubatuba, Brazil, San Juan, Puerto Rico and Brasilia, Brazil, among others Inter American Institute for Global Changes (CRN-12), Conselho Nacional de Desenvolvimento e 
Pesquisa do Brasil (CNPq), Programa PROSUL; University of São Paulo, Cornell University, and Fundación Antorchas of Argentina.

\section{References}

Alves B.J.R., Boddey R.M. and Urquiaga S. 2003. The success of BNF in soybean in Brazil. Plant Soil 252: 1-9.

Austin A.T., Howarth R.H., Baron J.S., Chapin III F.S., Christensen T.R., Holland E.A., Ivanov M.V., Lien A.Y., Martinelli L.A., Melillo J.M. and Shang C. 2003. Human disrpution of element interactions: drivers, consequences and trends for the 21st century. In: Melillo J.M., Field C.B. and Moldan B. (eds), Interactions of Major Biogeochemical Cycles: Global Change and Human Impacts, Island Press, Washington DC, pp. 15-46.

Austin A.T., Piñiero G. and Gonzalez Polo M. More is less: agricultural impacts on the N cycle in Argentina. Biogeochemistry (this volume).

Boddey R.M., Urquiaga S., Reis V.M. and Döbereiner J. 1991. Biological nitrogen fixation associated with sugarcane. Plant Soil 137: 111-117.

Boddey R.M., Urquiaga S., Alves B.J.R. and Reis V. 2003. Endophytic nitrogen fixation in sugarcare: present knowledge and future applications. Plant Soil 252: 139-149.

Boddey R.M., Macedo R., Tarre R.M., Ferreira E., de Oliveira O.C., Rezende C.P., Cantarutti R.B., Pereira J.M., Alves B.J.R. and Urquiaga S. 2004. Nitrogen cycling in Brachiaria pastures: the key to understanding the process of pasture decline. Agric. Ecosyst. Environ. 103: 389-403.

Daniel M.H.B., Montebello A.A., Bernardes M.C., Ometto J.P.H.B., Camargo P.B., Krusche A.V., Ballester M.V., Victoria R.L. and Martinell L.A. 2002. Effects of urban sewage on dissolved oxygen, dissolved inorganic carbon and organic carbon, and electrical conductivity of small streams along a gradient of urbanization in the Piracicaba River basin. Water Air Soil Poll. 136: 189-206.

Dentener F.J. and Crutzen P.J. 1994. A three-dimentional model of the global ammonia cycle. J. Atmos. Chem. 19: 331-369.

FAOSTAT. 2004. Food and Agriculture Organization of the United Nations, Statistical Databases [online] URL: http://www.apps.fao.org/.

Filoso S., Martinelli L.A., Howarth R.W., Boyer E.W. and Dentener F. Human activities changing the $\mathrm{N}$ cycle in Brazil. Biogeochemistry (this volume).

FRA 2000 - Global Forest Resources Assessment. 2000. Food and Agriculture Organization of the United Nations. Forestry Department.

Galanter M., Levy II H. and Carmichael G.R. 2000. Impacts of biomass burning on tropospheric $\mathrm{CO}, \mathrm{NO}_{x}$, and $\mathrm{O}_{3}$. J. Geophys. Res. 105(D5): 6633-6653.

Galloway J.N. 2003. Acid deposition: S and N cascades and elemental interactions. In: Melillo J.M., Field C.B. and Moldan B. (eds), Interactions of the Major Biogeochemical Cycles. Global Changes and Human Impacts, Island Press, Washington DC, pp. 259-272.

Galloway J.N. and Cowling E.B. 2002. Reactive nitrogen and the world: 200 years of change. Ambio 31: 64-71.

Galloway J.N., Dentener F.J., Capone D.G., Boyer E.W., Howarth R.W., Seitzinger S.P., Asner G.P., Cleveland C., Green P., Holland E., Karl D.M., Michaels A.F., Porter J.H., Townsend A. and Vorösmarty C. 2004. Nitrogen cycles: past, present and future. Biogeochemistry 70(2): 153-226.

Global Environment Outlook 3. 2003. Past, present and future perspectives. United Nations Environmental Programme.

Global Water Supply and Sanitation Assessment. 2000. World Health Organization - UNICEF Joint Monitoring Programme for Water Supply and Sanitation.

Holland E.A. and Carroll M.A. 2003. Linking the bio-atmosphere carbon and nitrogen cycles and atmospheric chemistry. In: Melillo J.M., Field C.B. and Moldan B. (eds), Interactions of the Major Biogeochemical Cyles. Global Changes and Human Impacts, Island Press, Washington DC, pp. 273-292. 
Holland E.A., Dentener F.J., Brasswell B.H. and \& Sulzman J.M. 1999. Contemporary and pre-industrial global reactive nitrogen budgets. Biogeochemistry 46: 7-43.

Howarth R.W., Boyer E.W., Pabich W.J. and Galloway J.N. 2002. Nitrogen use in the United States from 1961-2000 and potential future trends. Ambio 31: 88-96.

Hoelzemann J.J., Schultz M.G., Brasseur G.P., Granier C. and Simon M. 2004. Global Wildland Fire Emission Model (GWEM): Evaluating the use of global area burnt satellite data. J. Geophys. Res. 109, D14S04, doi:10.1029/2003JD003666.

Human Development Report. 2003. Millennium Development Goals: a compact among nations to end human poverty (2003). United Nations Development Programme (UNDP), Oxford University Press, New York.

INPE. 2004. Monitoramento da floresta Amazonica brasileira por satelite - Projeto PRODES. Instituto Nacional de Pesquisas Espaciais, [online] URL: http://www.obt.inpe.br/prodes/.

Lara L.L., Holland E.A., Artaxo P., Camargo P.B. and Martinelli L.A. Linking nitrogen deposition patterns and land use change in tropical areas. Biogeochemistry (this volume).

Martinelli L.A., Krusche A.V., Victoria R.L., Camargo P.B., Bernardes M.C., Ferraz E.S., Moraes J.M. and Ballester M.V. 1999. Effects of sewage on the chemical composition of Piracicaba River, Brazil. Water Air Soil Poll. 110: 67-79.

Martinelli L.A., Silva A.M., Camargo P.B., Moretti L.R., Tomazelli A.C., Silva D.M.L., Fischer E.G., Sonoda K.C. and Salomão M.S.M.B. 2002. Levantamento das cargas orgânicas lançadas nos rios do Estado de São Paulo. Biota Neotrópica 2: 1-18.

Miranda C.H.B. and Boddey R.M. 1987. Estimation of biological nitrogen fixation with 11 ecotypes of Panicum maximum grown in nitrogen-15 labeled soil. Agron. J. 79: 558-563.

Mosier A.R., Syers J.K. and Freney J.R. 2004. Nitrogen fertilizer: an essential component of increased food, feed and fiber production. In: Mosier A.R., Keith Syers J. and Freney J.R. (eds), Agriculture and the Nitrogen Cycle, Assessing the Impacts of Fertilizer Use on Food Production and the Environment SCOPE 65, Island Press, Washington DC, pp. 3-18.

Oliveira M.E.D., Vaughan B.E. and Rykiel Jr. E.J. 2005. Ethanol as fuel: energy, carbon dioxide balances, and ecological footprint. Bioscience 55: 593-602.

Potter C., Genovese V.B., Klooster S. and Torregrosa A. 2002. Biomass burning emissions of reactive gases estimated from satellite data analysis and ecosystem modeling for the Brazilian Amazon region. J. Geophys. Res. 107((D20)): Art. No. 8056.

Schultz M.G. 2002. On the use of ATSR fire count data to estimate the seasonal and interannual variability of vegetation fire emissions. Atmos. Chem. Phys. 2: 387-395.

Schurkes J.A. and Mosello R. 1988. The role of external ammonium inputs in freshwater acidification. Schweiz. Zeit. Hydrol. 88: 71-86.

Trebbs I., Lara L. L., Zeri L. M. M., Gatti L. V., Artaxo P., Dlugi R., Slanina J., Andreae M. O. and Meixner F. X. 2006. Dry and wet deposition of inorganic nitrogen compounds to a tropical pasture site (Rondônia, Brazil). Atmos. Chem. Phys. 6: 447-469.

Williams M.R. and Melack J.M. 1997. Solute export from forested and partially deforested catchments in the central Amazon. Biogeochemistry 38: 67-102.

World Urbanization Prospects. 2003. The 2003 Revision (2004) Department of Economic and Social Affairs. Population Division, United Nations, New York. 